\title{
Determinants of Bankruptcy: Evidence From Financially Distressed Firms
}

\author{
Sheng Yi \\ California State University, Dominguez Hills \\ Xiaojie Christine Sun \\ California State University, Los Angeles \\ Zenghui Liu \\ Western Washington University
}

\begin{abstract}
This study examines whether and how external monitoring, managerial ability, and investment decisions impact a financially distressed firm's probability of future bankruptcy. We find that a financially distressed firm with higher institutional ownership or higher managerial ability is less likely to file for bankruptcy. Additionally, a financially distressed firm's non-capital expenditure investment is negatively associated with its probability of bankruptcy. This study provides empirical evidence that external monitoring, competence of management, and non-capital expenditure investment should be considered when predicting bankruptcy among financially distressed firms. Our results are of particular interest to managers, lenders, financial institutions, and credit rating agencies.
\end{abstract}

Keywords: determinants of bankruptcy, external monitoring, managerial ability, non-capital expenditure

\section{INTRODUCTION}

Corporate bankruptcy results in significant costs to multiple stakeholders, such as shareholders, creditors, employees, investors, suppliers, customers, and the community (Eckbo, et al., 2016; Cooper and Uzun, 2019). For example, in the early 2000s, shareholders lost $\$ 460$ billion during the financial scandals involving WorldCom, Qwest, Global Crossing, Tyco, and Enron (Cotton, 2002; Lucci, 2003). Concordantly, a series of academic research attempts to explore characteristics that predict firm bankruptcy. Our study extends this line of research and investigates determinants of bankruptcy for financially distressed firms from three perspectives: external monitoring, managerial ability, and investment decisions.

The demand for an appropriate bankruptcy prediction model, serving as an early warning signal of corporate failure, increasingly attracts the attention of practitioners, regulators, and researchers, especially after the implementation of the Sarbanes-Oxley (SOX) Act (Chan, et al., 2016). Early academic research focuses on the impacts of companies' accounting and market variables (Altman, 1968; Ohlson, 1980; Zmijewski, 1984; Begley, et al., 1996; Shumway, 2001; Hillegeist, et al., 2004). Several recent studies examine the predictive power of corporate governance factors, such as board size and independence (Fich and Slezak, 2008; Darrat, et al., 2016; Goktan, et al., 2018), compensation committee (Chan, et al., 2016), and nomination committee (Appiah and Chizema, 2016). However, certain factors that play an essential 
role in firm performance are excluded in the bankruptcy prediction model, leading to concerns with potential omitted variables (Chancharat and Chancharat, 2013).

One example is a firm's external monitoring, such as the level of institutional ownership. Institutional investors have the incentives and resources to monitor managers to act in shareholders' best interests (Shleifer and Vishny, 1986; Cornett, et al., 2007). Several prior studies find evidence that large institutional shareholdings constrain managers' earnings management behavior (Chung, et al., 2002), leading to better firm performances (McConnell and Servaes, 1990; Cornett, et al., 2007). Therefore, it is expected that institutional investors may interfere with firms' corporate governance and influence their bankruptcy decisions. Another factor is managerial ability. Management makes day-to-day decisions which ultimately leads their firm toward its goals (Cooper and Uzun, 2019). A manager's knowledge, competence, and capability determine whether they could make adequate decisions impacting the chances of firm survival. Lastly, a firm's investment decisions may contribute to predicting firm bankruptcy. Overinvestment in longterm capital expenditures may benefit the company in the long run but limit a firm's ability to generate cash flows in the short term. Non-capital investment, on the other hand, may improve a firm's innovation and productivity, which are essential for a firm's survival. In summary, examining whether these three factors, institutional ownership, managerial ability, and investment decisions, significantly impact the probability of bankruptcy is theoretically and economically meaningful to regulators, practitioners, and researchers.

We use the financially distressed firms in the U.S. during 2000-2016 as our sample for two reasons. First, previous academic findings for healthy firms may not hold for distressed firms (Parker, et al., 2002; Fich and Slezak, 2008; Darrat, et al., 2016). For example, while managers are expected to seek long-term benefits for healthy firms, they may have more incentives to engage in opportunistic behavior to maximize their personal wealth when a firm is financially distressed (Myers, 1977; Richardson and Waegelein, 2002; Fich and Slezak, 2008). Likewise, investment in capital expenditures may benefit healthy firms with cash flows in the long run, but it may create liquidity problems for distressed firms. Second, including both healthy and distressed firms in a sample may generate endogeneity problems. For example, Darrat, et al. (2016) argue that firms that go bankrupt are generally smaller, mechanically resulting in a higher percentage of institutional ownership. Therefore, using only the distressed firms is a more appropriate setting to examine whether and how institutional ownership, managerial ability, and investment decisions contribute to predicting bankruptcy.

Our results indicate that larger institutional ownership is associated with a lower probability of future bankruptcy for financially distressed firms, suggesting that institutional investors provide efficient external monitoring and additional resources for a firm to survive. Additionally, we find a negative relationship between managerial ability and bankruptcy filings, consistent with the notion that capable managers make adequate decisions and lead to higher firm values. Lastly, capital expenditures are found to have no impact in predicting bankruptcy while non-capital expenditures lower the probability of bankruptcy for financially distressed firms. Investment in non-capital expenditures during financial distress periods may increase productivity or create new product lines, which help with a firm's survival. Our results are consistent to a series of robustness tests with an alternative measurement of financial distress and different sample periods.

This paper has the following contributions. First, our results contribute to the improvement of the bankruptcy prediction model. While factors of external monitoring, managerial ability, and research and development investment decisions are found to be essential in determining firms' performance, they have not been included in the bankruptcy prediction models of financially distressed firms in prior studies. This study shows how these three factors affect the probability of bankruptcy for financially distressed firms. Second, this study contributes to literature related to financially distressed firms, whose operating strategies may be different from healthy firms (Parker, et al., 2002). Prior research finds that corporate governance, such as CEO turnover, blockholder, insider ownership, and board characteristics, are significantly related to bankruptcy of distressed firms (Parker, et al., 2002; Fich and Slezak, 2008). Our results extend these studies and document that external institutional shareholders, managerial ability, and investment decisions play an essential role in a financially distressed firm's operations. Third, this study provides practical implications. Our analysis contributes to enhancing the bankruptcy prediction model, which is important to 
related parties, such as regulators, investors, lenders, financial institutions, and credit rating agencies, who attempt to identify the probability of bankruptcy for financially distressed firms.

The remainder of this paper is organized as follows. Section 2 develops the hypotheses. Section 3 outlines the sample selection and regression models. Section 4 and Section 5 reports the empirical results and robustness tests. Section 6 concludes.

\section{HYPOTHESES DEVELOPMENT}

\section{Determinants of Bankruptcy}

According to the Bankruptcy Reform Act 1978 and 2005, firms in the United States may file under Chapter 7 for liquidation bankruptcy or Chapter 11 for reorganization bankruptcy (Thorburn, et al., 2013). Given the severe negative consequences of bankruptcy for the shareholders, employees, and society, there is a series of academic research exploring the determinants of bankruptcy. For example, a firm's efficiency, productivity, liquidity, financing frictions, and credit constraints are found to significantly impact the probability of bankruptcy (Ericson and Pakes, 1995; Olley and Pakes, 1992; Dwyer, 1998; Cooley and Quadrini, 2001; Fariñas and Ruano, 2005; Ni, et al., 2014; Osotimehin and Pappadà, 2017; Aleksanyan and Huiban, 2016). Several recent studies demonstrate other determinants of bankruptcy. For example, Buehler, et al. (2010) provide evidence that bankruptcy is significantly related to geographic areas. Bryan, et al. (2014) find a positive association between fraud and bankruptcy filing. Zorn, et al. (2017) state that the likelihood of bankruptcy is significantly increased for downsizing firms. Cooper and Uzun (2019) report that bankruptcy is less likely to occur for firms with a more substantial corporate social responsibility. Lastly, Biddle, et al. (2020) find evidence that accounting conservatism is negatively related to bankruptcy risk.

Prior literature also demonstrates that including corporate governance characteristics increases the prediction power of the bankruptcy prediction model (Fich and Slezak, 2008). Specifically, Parker, et al. (2002) find that CEO turnover is positively, while blockholder and insider ownership are negatively, related to bankruptcy. Fich and Slezak (2008) report evidence that distressed firms are more likely to avoid bankruptcy if their boards are smaller and more independent. Contrary to Fich and Slezak (2008), Darrat, et al. (2016) demonstrate that larger boards inversely impact the likelihood of bankruptcy only for complex firms. Furthermore, the authors find empirical evidence that board diversification, management stability, and CEO power are significantly associated with bankruptcy. Goktan, et al. (2018) also find that smaller and less independent boards are positively associated with bankruptcy. Moreover, Chan, et al. (2016) and Appiah and Chizema (2016) find a significant relationship between bankruptcy and characteristics of firms' compensation and nomination committees.

To sum up, existing research shows evidence that both endogenous and exogenous factors affect firms' bankruptcy decisions. In this study, we focus on institutional ownership, managerial ability, and investment decisions and explore whether these factors help firms survive during the financial distress period.

\section{Institutional Ownership}

Institutional shareholders are generally considered as an external monitoring mechanism that provides a "safety net" for firm performance (Badrinath, et al., 1989). Shleifer and Vishny (1986) claim that large institutional shareholders have more incentives than the board of directors to monitor managers' behaviors. Consistently, prior research provides evidence that institutional investors constrain managers' opportunistic behaviors and make them focus on firms' benefits (McConnell and Servaes, 1990; Nesbitt, 1994; Smith, 1996; Del Guercio and Hawkins, 1999; Chung, et al., 2002). Moreover, given their holding size and analytical skills, large institutional investors are believed to have the professional resources and ability to be influential in certain decisions and strategies of firms (Cornett, et al., 2007).

Kane and Velury (2004) argue that institutional shareholders may provide monitoring functions in two ways. First, institutional shareholders may directly vote during the management decision process through the voting rights derived from their holdings of a large amount of common stocks. Second, institutional 
shareholders may indirectly affect firm decisions by buying and selling their holdings, which impacts the firms' cost of capital.

Consistently, prior literature provides empirical evidence that institutional shareholders, who provide extra monitoring functions, help reduce the agency costs, which in turn improves firm value. For example, McConnell and Servaes (1990), Nesbitt (1994), and Del Guercio and Hawkins (1999) report a positive relationship between institutional ownership and firm performance. Kane and Velury (2004) find that institutional ownership is associated with higher audit quality. Ramalingegowda and $\mathrm{Yu}$ (2012) document evidence that higher institutional ownership leads to more conservative financial reporting. Moreover, Aghion, et al. (2013) provides evidence that innovation is positively impacted by institutional ownership.

Contrarily, several prior studies find no evidence that institutional ownership is significantly associated with firm performance (Agrawal and Knoeber, 1996; Karpoff, et al., 1996; Duggal and Millar, 1999; Faccio and Lasfer, 2000). Likewise, Wahal (1996), Smith (1996), and Opler and Sokobin (1997) document that institutional ownership improves firm performance only in limited cases.

Regarding the relationship between institutional ownership and bankruptcy, Darrat, et al. (2016) report a positive impact of institutional ownership on bankruptcy risks, inconsistent with the authors' expectations. The authors argue that the possible reason may be the potential endogeneity problems. That is, the authors use all public firms as their sample, which includes both bankruptcy firms and healthy firms. It is possible that the bankruptcy firms are generally smaller, resulting in a higher percentage of shares held by institutional shareholders.

In our study, we use financially distressed firms as our sample to diminish the potential endogeneity problem. Suppose the institutional shareholders utilize their influencing power to guide the firms with decisions that benefit the firms. In that case, we expect that firms may be less likely to go bankruptcy during the financial distress period. On the other hand, it is possible that institutional shareholders have no significant influence on firms' financial distress problems. Then we may not find a significant relationship between bankruptcy and institutional ownership. We state our hypothesis in null form as follows:

H1: There is no association between bankruptcy and institutional ownership for financially distressed firms.

\section{Managerial Ability}

Management plays a crucial role in companies' bankruptcy decisions, and a majority of the bankruptcy filings are initiated by the managers (Hotchkiss, et al., 2008). Given the information asymmetry, creditors or other outside users may not be aware of the firm's actual financial situation. Therefore, managers may choose to continue to operate the companies in line with their own interests. For example, managers may undertake high-risk projects, which may harm the firm's value in the long run to avoid their penalty of filing bankruptcy (Aghion, et al., 1992; White, 1994).

It is expected that managers with different skills and capabilities may influence the likelihood of bankruptcy during firms' financial distress periods. On the one hand, managers with higher abilities are more likely to understand the firm deeply and lead the firm with better resources and environment. For example, Bonsall, et al. (2017) find that higher managerial ability is associated with more consistent stock returns and higher credit ratings. Baik, et al. (2018) report that managerial ability is positively related to firms' information environment. Yung and Chen (2018) suggest that high-ability managers are more willing to take risks and invest in R\&D projects, thus increasing firm value. Furthermore, Lee, et al. (2018) document evidence that managers with high abilities are able to gain better investment opportunities, which results in more profits for the company. Therefore, it is expected that, for firms with financial distress, if their managers are more capable of making adequate investment decisions, they may be less likely to go bankrupt.

On the other hand, several prior studies document that the effect of managerial ability may not be favorable to firm value. For example, Mishra (2014) reports that managers with better skills may result in more agency problems and higher required returns from investors. Moreover, Cho, et al. (2016) argue that the effect of management on corporate innovation may be limited, compared to firm characteristics. 
Therefore, the impact of managerial ability on bankruptcy is not certain. To sum up, we state our hypothesis in null form as follows:

H2: There is no association between bankruptcy and managerial ability for financially distressed firms.

\section{Investment Decisions}

A company's capital and non-capital investment may influence its going-concern operations. For example, capital expenditures are expected to generate positive net present value in the long run, leading to higher firm value (McConnell and Muscarella, 1985; Chung, et al., 1998). However, they are generally associated with long-term contract obligations that a financially distressed firm may be unable to pay. Thus, this type of investment is considered an illiquid asset, which may become a problem leading to bankruptcy (Darrat, et al., 2016).

On the other hand, non-capital expenditures, such as the R\&D expenditure, are generally without the long-term obligations and may significantly contribute to innovation, productivity, and new product lines, benefiting distressed firms' survival (Mairesse and Mohnen, 2004). Consistently, we state our hypothesis in null form as follows:

H3: There is no association between bankruptcy and capital/non-capital investment for financially distressed firms.

\section{SAMPLE SELECTION AND REGRESSION MODELS}

\section{Sample}

Our sample starts with all U.S. public companies in COMPUSTAT from 2000 to 2014. The bankruptcy data is obtained from the Audit Analytics Bankruptcies database, which tracks bankruptcy declarations since 2000. Following Campbell, et al. (2008), we use those bankruptcy declarations under Chapters 7 or Chapter 11. The institutional shareholder data is from Thomson Reuters Database. We exclude firms in financial services or utility industries as well as observations with missing data required for our analysis.

\section{Measurement}

Financially Distressed Firms

To obtain the firms' financial situation, we calculate the Altman $Z$ score, a proxy for financial distress and bankruptcy risk, based on five financial ratios using the formula below (Altman, 1968):

$Z_{-}$score $=1.2 A+1.4 B+3.3 C+0.6 D+1.0 E$

where: $\mathrm{A}=$ working capital/total assets; $\mathrm{B}=$ retained earnings/total assets; $\mathrm{C}=$ earnings before interest and tax/total assets; $\mathrm{D}=$ market value of equity/total liabilities; and $\mathrm{E}=$ sales/total assets

Following Altman (1968), a $Z$ _score larger than 2.67 implies financial soundness, while a score smaller than 1.81 suggests financial distress. A $Z_{-}$score between 1.81 and 2.67 often represents the grey area. We define a financially distressed firm as its $Z$ score smaller than 1.81. Our final sample consists of 9,854 financially distressed firm-years from 2000 to 2014 . Table 1 summarizes the sample selection procedure.

\section{Institutional Ownership}

Institutional ownership is measured as the number of shares owned by institutional shareholders divided by the total shares outstanding (Darrat, et al., 2016). Higher institutional ownership indicates a more sufficient external monitoring for the firm. 
TABLE 1

\section{SAMPLE SELECTION}

\begin{tabular}{|l|c|}
\hline Description & Observations \\
\hline Compustat listed firms from the year 2000 to 2014 & 72,659 \\
\hline Less: Firm-year observations with missing data to calculate $M A \_s c o r e$ & $(21,105)$ \\
\hline Less: Firms in utility and financial industry (SIC 4400-5000 and SIC 6000-6999) & $(2,739)$ \\
\hline Less: Not financially distressed firm-years (i.e. $Z$ score $>=1.81)$ & $(32,191)$ \\
\hline Less: Firm-year observations with missing data to calculate variables & $(6,770)$ \\
\hline Final financially distressed firm sample & 9,854 \\
\hline
\end{tabular}

\section{Managerial Ability}

To measure managerial ability, we followed Demerjian, et al. (2012). First, for all the firm years on Compustat, we use sales revenue (Sales) as the output and the following variables as inputs: cost of goods sold $(C O G S)$, selling, general, and administrative expenses $(S G \& A)$, net property, plant, and equipment $(P P E)$, capitalized operating leases (OpsLease), capitalized research and development $(R \& D)$, purchased goodwill (Goodwill), and other intangibles (OtherIntan). Using those inputs and outputs, we solves the following optimization problem within each industry:

$\max _{v} \theta=\frac{\text { Sales }}{v_{1} C O G S+v_{2} S G \& A+v_{3} P P E+v_{4} O p \text { sLease }+v_{5} R \& D+v_{6} G o o d w i l l+v_{7} \text { OtherIntan }}$

Second, the firm efficiency scores obtained in Equation (2) are regressed on firm characteristics using the following model:

Firm Efficiency $=\alpha_{0}+\alpha_{1} \operatorname{In}($ Assets $)+\alpha_{2}$ Market $+\alpha_{3}$ Free Cash Flow $+\alpha_{4} \operatorname{Ln}($ Age $)$ $+\alpha_{5}$ Business Segment $+\alpha_{6}$ Foreign + Year Indicators $+\varepsilon$

Assets is a firm's total assets; Market is the percentage of a firm's revenue within its industry; Free Cash Flow equals to one if a firm reports nonnegative free cash flow; Age is a firm's age; Business Segment is the ratio of individual business segment sales to total sales; Foreign equals to one if a firm reports a nonzero value for foreign currency adjustment.

The residuals from Equation (3) is our measure of managerial ability.

\section{Capital vs. Non-Capital Expenditure}

Following Biddle, et al. (2009), we divide investment between capital expenditure (Capex) and noncapital expenditure (NonCapex). Capex is capital expenditure multiplied by 100 and scaled by lagged property, plant, and equipment. NonCapex is the sum of research and development expenditure and acquisition expenditure multiplied by 100 and scaled by lagged total assets.

\section{Regression Model}

To examine our hypotheses, we perform the logit regression of firm bankruptcy on institutional ownership, managerial ability, capital expenditure, and non-capital expenditure using Equation (4):

Bankruptcy $=\alpha_{0}+\alpha_{1}$ Ins $_{\text {Shares }}+\alpha_{2} M A_{\text {Score }}+\alpha_{3}$ Capex $+\alpha_{4}$ NonCapex + $\sum$ Controls + IndustryFE + YearFE $+\varepsilon$

where the dependent variable is Bankruptcy, which is a dummy variable that equals 1 if the firm bankrupts within two years of the financial reporting date, and 0 otherwise. We control for an array of firm characteristics, including size $(\log A T)$, book to market ratio $(B M)$, leverage (Leverage), and return on assets 
$(R O A)$. Industry and year-fixed effects are included to control for industry and time-level factors. Detailed variable definitions are presented in APPENDIX.

\section{EMPIRICAL RESULTS}

\section{Descriptive Statistics}

Panel A of Table 2 presents the descriptive statistics of the variables. The mean and median $Z_{-}$score is -9.461 and -1.026 , consistent with our sample only consisting of financially distressed firms. Approximately 6.40 percent of firms in our sample file bankruptcy, suggesting the economic significance of this phenomenon. The average institutional ownership (Ins_shares) is 17.6 percent. The mean MA score is 0.015 , indicating the managerial ability in financially distressed firms is lower than healthy firms. For example, the mean managerial ability is -0.004 in Demerjian, et al. (2012) and 0.00 in in Demerjian, et al. (2013). And the means of Capex and Noncapex are 43.585 and 22.799, respectively. For control variables, the means of $\log A T, B M$, and Leverage are 3.920, -0.101 , and 1.108 , respectively. The majority of the sample firms experience negative $R O A$ with a mean of -0.496 , again consistent with the financially distressed firm sample.

The Pearson correlation matrix of all variables is shown in Panel B of Table 2. We find that Bankruptcy is negatively correlated with institutional ownership (Ins_shares), managerial ability (MA_score), and noncapital expenditures (NonCapex). Results also indicate a significant correlation between control variables. For example, firm size $(\log A T)$ is positively correlated with $B M$ and $R O A$ and negatively correlated with Leverage.

TABLE 2

DESCRIPTIVE STATISTICS AND CORRELATION MATRIX

\begin{tabular}{|c|c|c|c|c|c|c|c|c|c|c|}
\hline \multicolumn{11}{|c|}{ Panel A: Descriptive Statistics } \\
\hline \multicolumn{3}{|c|}{ Variable } & \multicolumn{2}{|c|}{$\mathrm{N}$} & Mean & Std & \multicolumn{2}{|c|}{ Q1 } & Median & Q3 \\
\hline \multicolumn{3}{|l|}{ Z_score } & \multicolumn{2}{|c|}{9,854} & -9.461 & 22.507 & \multicolumn{2}{|c|}{-7.752} & -1.026 & 0.904 \\
\hline \multicolumn{3}{|l|}{ Bankruptcy } & \multicolumn{2}{|c|}{9,854} & 0.064 & 0.244 & \multicolumn{2}{|c|}{0.000} & 0.000 & 0.000 \\
\hline \multicolumn{3}{|l|}{ Ins_shares } & \multicolumn{2}{|c|}{9,854} & 0.176 & 0.296 & \multicolumn{2}{|c|}{0.000} & 0.000 & 0.254 \\
\hline \multicolumn{3}{|l|}{ MA score } & \multicolumn{2}{|c|}{9,854} & -0.015 & 0.112 & \multicolumn{2}{|c|}{-0.083} & -0.029 & 0.031 \\
\hline \multicolumn{3}{|l|}{ Capex } & \multicolumn{2}{|c|}{9,854} & 43.585 & 96.744 & \multicolumn{2}{|c|}{6.753} & 16.922 & 39.440 \\
\hline \multicolumn{3}{|l|}{ Noncapex } & \multicolumn{2}{|c|}{9,854} & 22.799 & 42.516 & \multicolumn{2}{|c|}{1.601} & 9.344 & 24.714 \\
\hline \multicolumn{3}{|l|}{$\log A T$} & \multicolumn{2}{|c|}{9,854} & 3.920 & 2.523 & \multicolumn{2}{|c|}{2.166} & 3.757 & 5.599 \\
\hline \multicolumn{3}{|l|}{$B M$} & \multicolumn{2}{|c|}{9,854} & -0.101 & 2.799 & \multicolumn{2}{|c|}{-0.070} & 0.278 & 0.755 \\
\hline \multicolumn{3}{|l|}{ Leverage } & \multicolumn{2}{|c|}{9,854} & 1.108 & 1.495 & \multicolumn{2}{|c|}{0.458} & 0.701 & 1.019 \\
\hline$R O A$ & & & & 54 & -0.496 & 0.869 & & 53 & -0.200 & -0.027 \\
\hline Panel B: Pea & 10 & relati & Matri & & & & & & & \\
\hline & 1) & 2) & 3) & 4) & 5) & 6) & 7) & 8) & 9) & 10) \\
\hline 1) $Z$ score & 1 & 0.00 & 0.23 & -0.13 & -0.01 & -0.26 & 0.55 & 0.25 & -0.76 & 0.70 \\
\hline 2) Bankruptcy & & 1 & -0.06 & -0.07 & 0.00 & -0.03 & $\mathbf{0 . 0 3}$ & -0.13 & 0.04 & -0.03 \\
\hline 3) Ins_shares & & & 1 & -0.06 & -0.03 & -0.04 & $\mathbf{0 . 5 3}$ & 0.12 & -0.16 & 0.23 \\
\hline 4) $M A$ score & & & & 1 & 0.04 & 0.15 & -0.24 & -0.04 & 0.10 & 0.01 \\
\hline 5) Capex & & & & & 1 & 0.32 & -0.03 & 0.04 & 0.00 & -0.12 \\
\hline 6) NonCapex & & & & & & 1 & -0.16 & -0.01 & 0.20 & -0.36 \\
\hline 7) $\log A T$ & & & & & & & 1 & 0.14 & -0.41 & 0.52 \\
\hline 8) $B M$ & & & & & & & & 1 & -0.41 & 0.16 \\
\hline 9) Leverage & & & & & & & & & 1 & -0.63 \\
\hline 10) $R O A$ & & & & & & & & & & 1 \\
\hline
\end{tabular}




\section{Multivariate Results}

Table 3 presents the logit regression results of Equation (4). We find a negative and significant coefficient of Ins_shares, suggesting that larger institutional ownership leads to fewer future bankruptcies for financially distressed firms. The results are consistent with prior studies that institutional investors perform as an external monitoring mechanism and may have incentives, capability, and resources to provide more efficient governance, helping firms to survive during financial distress years.

Results also show a negative association between managerial ability and the likelihood of future bankruptcy. As an essential player in the years of financial distress, an efficient management team is more capable of generating resources and making decisions to help firms survive the financial distress, leading to less bankruptcy filing.

Regarding investment decisions, we find that capital expenditures have no impact on bankruptcy while non-capital expenditures are negatively related to bankruptcy. Companies devoting into R\&D and acquisition expenditures are likely to develop additional markets, which helps firms pass through the financial distress period.

Additionally, the results of control variables suggest that firms with a higher book-to-market ratio and ROA are less likely to file bankruptcy during their financial distress years. Larger firms are found to have a higher probability of filing bankruptcy. We do not find a significant relationship between bankruptcy and leverage of financial distressed firms, possibly because financial distressed firms already bear a high level of leverage.

TABLE 3

\section{MULTIVARIATE REGRESSION RESULTS}

\begin{tabular}{|l|c|c|}
\hline Dependent Variable: Bankruptcy & T-value \\
\hline Parameter & Coefficient & $-6.49^{* * *}$ \\
\hline Intercept & -3.137 & $-5.09^{* * *}$ \\
\hline Ins_shares & -0.894 & $-3.54^{* * *}$ \\
\hline MA_score & -2.072 & 0.48 \\
\hline Capex & 0.000 & $-1.83^{*}$ \\
\hline NonCapex & -0.003 & $5.95^{* * *}$ \\
\hline LogAT & 0.124 & $-6.13^{* * *}$ \\
\hline BM & -0.085 & 1.46 \\
\hline Leverage & 0.052 & $-3.07^{* * *}$ \\
\hline ROA & -0.204 & \\
\hline Industry Fixed Effects & Yes & \\
\hline Year Fixed Effects & Yes & \\
\hline$N$ & 9,854 & \\
\hline Adj. $R$-squared & $7.20 \%$ & \\
\hline$*, * *, * *$ indicate significance at $0.10,0.05$, and 0.01 level, respectively. \\
Standard errors are clustered by year and industry. \\
The variable definitions are in APPENDIX A. & \\
\hline
\end{tabular}

\section{ROBUSTNESS TESTS}

We perform several robustness tests to reexamine the viability of our results. First, we use the $B S M \_$score to reclassify financially distressed firms. BSM_score is a market-based measure of the probability of bankruptcy that Hillegeist, et al. (2004) developed based on the Black-Scholes-Merton option-pricing model. The SAS code of the BSM_score is in Appendix A of Hillegeist, et al. (2004).We chose the highest quartile of BSM_score among all the firm years from 2000-2014, representing those firms years with the highest probability of bankruptcy. There are 5,915 firm-years classified as financially 
distressed firms during our sample period. We rerun our main test using Equation (4) and results are shown in Table 4. We find consistent results for our main variables. Specifically, institutional ownership (Ins_shares), managerial ability (MA_score), and non-capital expenditures (NonCapex) are negatively associated with bankruptcy. The adjusted $\mathrm{R}$ square is higher than using accounting-based measures (i.e. $Z$ _score), consistent with Hillegeist, et al. (2004) that BSM_score provides significantly more information than accounting-based bankruptcy measures.

TABLE 4

\section{ROBUSTNESS TEST USING ALTERNATIVE FINANCIAL DISTRESS MEASURE}

\begin{tabular}{|l|c|c|}
\hline Dependent Variable: Bankruptcy & T-value \\
\hline Parameter & -3.864 & $-4.03^{* * *}$ \\
\hline Intercept & -1.573 & $-4.58^{* * *}$ \\
\hline Ins_shares & -2.158 & $-2.04^{* *}$ \\
\hline MA_score & 0.000 & 0.11 \\
\hline Capex & -0.021 & $-2.39^{* *}$ \\
\hline NonCapex & 0.095 & $1.75^{*}$ \\
\hline LogAT & 0.086 & 0.69 \\
\hline BM & 1.790 & $6.05^{* * *}$ \\
\hline Leverage & -2.241 & $-6.55^{* * *}$ \\
\hline ROA & Yes & \\
\hline Industry Fixed Effects & Yes & \\
\hline Year Fixed Effects & 5,916 & \\
\hline$N$ & $20.38 \%$ & \\
\hline Adj. R-squared $* *$ indicate significance at 0.10, 0.05, and 0.01 level, respectively. \\
\hline$* * *, * *$ ind \\
Standard errors are clustered by year and industry. \\
The variable definitions are in APPENDIX.
\end{tabular}

Second, we alternatively measure the dependent variable (Bankruptcy) as the firm filing for bankruptcy within three or five years to examine whether the impact of institutional ownership, managerial ability, and investment decisions holds in more extended periods. As shown in Table 5, the results are consistent with our main findings, suggesting that the prediction power of institutional ownership, managerial ability, and investment decisions on bankruptcy are not influenced by our measure of bankruptcy.

TABLE 5

\section{ROBUSTNESS TEST USING ALTERNATIVE BANKRUPTCY MEASURES}

\begin{tabular}{|l|c|c|c|c|}
\hline & \multicolumn{2}{|l|}{ Bankruptcy in 3 years } & \multicolumn{2}{l|}{ Bankruptcy in 5 years } \\
\hline Parameter & Coefficient & T-value & Coefficient & T-value \\
\hline Intercept & -2.643 & $-7.92^{* * *}$ & -2.011 & $-6.69^{* * *}$ \\
\hline Ins_shares & -1.141 & $-6.92^{* * *}$ & -1.315 & $-8.64^{* * *}$ \\
\hline MA_score & -2.088 & $-3.89^{* * *}$ & -1.542 & $-3.32^{* * *}$ \\
\hline Capex & 0.000 & -0.25 & 0.000 & 0.29 \\
\hline NonCapex & -0.003 & $-2.48^{* *}$ & -0.003 & $-2.40^{* *}$ \\
\hline LogAT & 0.135 & $6.75^{* * *}$ & 0.141 & $7.21^{* * *}$ \\
\hline BM & -0.081 & $-6.81^{* * *}$ & -0.060 & $-5.57^{* * *}$ \\
\hline Leverage & 0.030 & 0.86 & 0.046 & 1.43 \\
\hline ROA & -0.282 & $-4.35^{* * *}$ & -0.254 & $-4.32^{* * *}$ \\
\hline Industry Fixed Effects & Yes & & Yes & \\
\hline
\end{tabular}




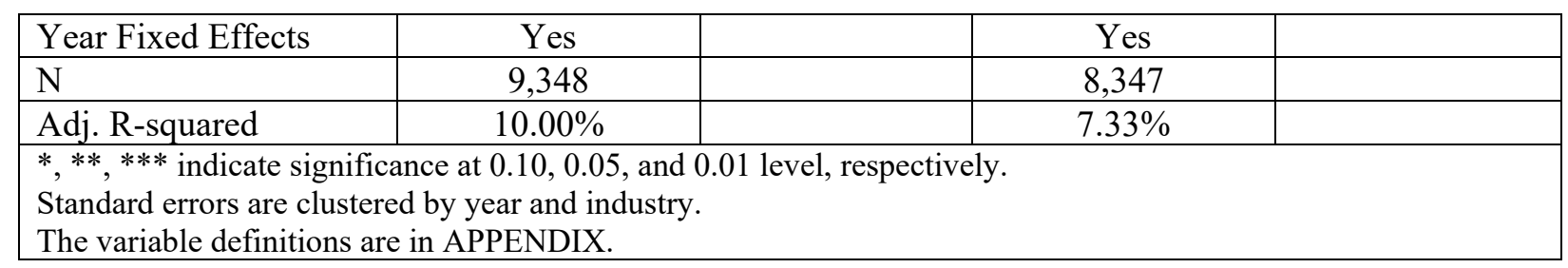

Third, SOX, which was issued after the early 2000s financial scandals, focuses on the efficiency of corporate governance, such as the independence and expertise of the board and audit committee. We eliminate these transition periods and rerun the main regression using only the sample after 2004. As shown in Table 6, the coefficients of Ins_shares, MA_score, and NonCapex are still negative and significant, consistent with the main results.

TABLE 6 ROBUSTNESS TEST USING ALTERNATIVE SAMPLE YEARS

\begin{tabular}{|l|c|c|}
\hline Dependent Variable: Bankruptcy & T-value \\
\hline Parameter & Coefficient & -1.29 \\
\hline Intercept & -0.798 & $-6.36^{* * *}$ \\
\hline Ins_shares & -1.180 & $-2.73^{* * *}$ \\
\hline MA_score & -1.592 & 1.11 \\
\hline Capex & 0.001 & $-2.47^{* *}$ \\
\hline NonCapex & -0.004 & $6.10^{* * *}$ \\
\hline LogAT & 0.171 & $-12.00^{* * *}$ \\
\hline BM & -0.342 & $-2.16^{* *}$ \\
\hline Leverage & -0.103 & $-3.07^{* * *}$ \\
\hline ROA & -0.277 & \\
\hline Industry Fixed Effects & Yes & \\
\hline Year Fixed Effects & Yes & \\
\hline$N$ & 5,768 & \\
\hline Adj. R-squared & $4.11 \%$ & \\
\hline$*, * * * *$ indicate significance at $0.10,0.05$, and 0.01 level, respectively. \\
Standard errors are clustered by year and industry. \\
The variable definitions are in APPENDIX. \\
\hline \multicolumn{2}{|l}{} \\
\hline
\end{tabular}

\section{CONCLUSION}

Given its significant economic impact, bankruptcy prediction has attracted attention from regulators, practitioners, and academics. Empirical literature mainly focuses on the impact of accounting, marketing, and corporate governance on firm bankruptcy decisions. However, there has been a call for incorporating the potential omitted variables in the bankruptcy prediction model (Chancharat and Chancharat, 2013). This study aims to improve this model and explores whether and how a firm's external monitoring, managerial ability, and investment decisions play a role in its probability of future bankruptcy.

Our results show that institutional investors, managerial ability, and non-capital expenditures are significantly related to bankruptcy of financially distressed firms and suggest that these factors should be included in the bankruptcy prediction model. Specifically, we find that the probability of bankruptcy is negatively associated with institutional ownership, managerial ability, and non-capital expenditures. This study fills in a gap in the bankruptcy literature by incorporating external and internal factors as well as investment decisions in bankruptcy prediction. Our results have significant implications for regulators, investors, and financial institutions. 


\section{REFERENCES}

Aghion, P., Hart, O., \& Moore, J. (1992). The economics of bankruptcy reform. National Bureau of Economic Research, 4097.

Aghion, P., Van Reenen, J., \& Zingales, L. (2013). Innovation and institutional ownership. American economic review, 103(1), 277-304.

Agrawal, A., \& Knoeber, C.R. (1996). Firm performance and mechanisms to control agency problems between managers and shareholders. Journal of Financial and Quantitative Analysis, 31(3), 377397.

Aleksanyan, L., \& Huiban, J.P. (2016). Economic and financial determinants of firm bankruptcy: evidence from the French food industry. Review of Agricultural, Food and Environmental Studies, 97(2), 89-108.

Altman, E. (1968). Financial ratios, discriminant analysis, and the prediction of corporate bankruptcy. Journal of Finance, 23(4), 589-609.

Appiah, K.O., \& Chizema, A. (2016). The impact of board quality and nomination committee on corporate bankruptcy. Advances in Accounting, 35, 75-81.

Badrinath, S.G., Gay, G.D., \& Kale, J.R. (1989). Patterns of institutional investment, prudence, and the managerial" safety-net" hypothesis. Journal of Risk and Insurance, pp. 605-629.

Baik, B., Brockman, P.A., Farber, D.B., \& Lee, S. (2018). Managerial ability and the quality of firms' information environment. Journal of Accounting, Auditing \& Finance, 33(4), 506-527.

Begley, J., Ming, J., \& Watts, S. (1996). Bankruptcy classification errors in the 1980s: An empirical analysis of Altman's and Ohlson's models. Review of Accounting Studies, 1, 267-284.

Biddle, G. C., Hilary, G., \& Verdi, R. S. (2009). How does financial reporting quality relate to investment efficiency? Journal of Accounting and Economics, 48(2-3), 112-131.

Biddle, G. C., Ma, M. L., \& Song, F. M. (2020). Accounting conservatism and bankruptcy risk. Journal of Accounting, Auditing \& Finance, pp. 1-19.

Bonsall, S.B., IV, Holzman, E.R., \& Miller, B.P. (2017). Managerial ability and credit risk assessment. Management Science, 63(5), 1425-1449.

Bryan, D., Janes, T., \& Tiras, S.L. (2014). The role that fraud has on bankruptcy and bankruptcy emergence. Journal of Forensic \& Investigative Accounting, 6(2), 126-156.

Buehler, S., Kaiser, C., \& Jaeger, F. (2012). The geographic determinants of bankruptcy: Evidence from Switzerland. Small Business Economics, 39(1), 231-251.

Campbell, J.Y., Hilscher, J., \& Szilagyi, J. (2008). In search of distress risk. The Journal of Finance, 63(6), 2899-2939.

Chan, C.Y., Chou, D.W., Lin, J.R., \& Liu, F.Y. (2016). The role of corporate governance in forecasting bankruptcy: Pre-and post-SOX enactment. The North American Journal of Economics and Finance, 35, 166-188.

Chancharat, S., \& Chancharat, N. (2013). Corporate governance and company survival. Humanities, Arts and Social Sciences, pp. 33-62.

Cho, C., Halford, J.T., Hsu, S., \& Ng, L. (2016). Do managers matter for corporate innovation? Journal of Corporate Finance, 36, 206-229.

Chung, K. H., Wright, P., \& Charoenwong, C. (1998). Investment opportunities and market reaction to capital expenditure decisions. Journal of Banking \& Finance, 22(1), 41-60.

Chung, R., Firth, M., \& Kim, J. (2002). Institutional monitoring and opportunistic earnings management. Journal of Corporate Finance, 8, 29-48.

Cooley, T.F., \& Quadrini, V. (2001). Financial markets and firm dynamics. American Economic Review, 91(5), 1286-1310.

Cooper, E., \& Uzun, H. (2019). Corporate social responsibility and bankruptcy. Studies in Economics and Finance, 36(2).

Cornett, M.M., Marcus, A.J., Saunders, A., \& Tehranian, H. (2007). The impact of institutional ownership on corporate operating performance. Journal of Banking \& Finance, 31(6), 1771-1794. 
Cotton, D. (2002, October). Fixing CPA Ethics Can Be an Insider Job. Retrieved from https://www.washingtonpost.com/archive/opinions/2002/10/20/fixing-cpa-ethics-can-be-aninside-job/b7441564-e0a6-431b-9280-8c27c6267ebc/

Darrat, A.F., Gray, S., Park, J.C., \& Wu, Y. (2016). Corporate governance and bankruptcy risk. Journal of Accounting, Auditing \& Finance, 31(2), 163-202.

Del Guercio, D., \& Hawkins, J. (1999). The motivation and impact of pension fund activism. Journal of Financial Economics, 52, 293-340.

Demerjian, P., Lev, B., \& McVay, S. (2012). Quantifying managerial ability: A new measure and validity tests. Management science, 58(7), 1229-1248.

Demerjian, P.R., Lev, B., Lewis, M.F., \& McVay, S.E. (2013). Managerial ability and earnings quality. The Accounting Review, 88(2), 463-498.

Duggal, R., \& Millar, J.A. (1999). Institutional ownership and firm performance: The case of bidder returns. Journal of Corporate Finance, 5(2), 103-117.

Dwyer, D.W. (1998). Technology locks, creative destruction, and nonconvergence in productivity levels. Review of Economic Dynamics, 1(2), 430-473.

Eckbo, B.E., Thorburn, K.S., \& Wang, W. (2016). How costly is corporate bankruptcy for the CEO? Journal of Financial Economics, 121(1), 210-229.

Ericson, R., \& Pakes, A. (1995). Markov-perfect industry dynamics: A framework for empirical work. The Review of Economic Studies, 62(1), 53-82.

Faccio, M., \& Lasfer, M.A. (2000). Do occupational pension funds monitor companies in which they hold large stakes? Journal of Corporate Finance, 6(1), 71-110.

Farinas, J.C., \& Ruano, S. (2005). Firm productivity, heterogeneity, sunk costs and market selection. International Journal of Industrial Organization, 23(7-8), 505-534.

Fich, E.M., \& Slezak, S.L. (2008). Can corporate governance save distressed firms from bankruptcy? An empirical analysis. Review of Quantitative Finance and Accounting, 30(2), 225-251.

Goktan, M.S., Kieschnick, R., \& Moussawi, R. (2018). Corporate governance and firm survival. Financial Review, 53(2), 209-253.

Hillegeist, S., Keating, E., Cram, D., \& Lundstedt, K. (2004). Assessing the probability of bankruptcy. Review of Accounting Studies, 9(1), 5-34

Hotchkiss, E.S., John, K., Mooradian, R.M., \& Thorburn, K.S. (2008). Bankruptcy and the resolution of financial distress. Handbook of Empirical Corporate Finance, pp. 235-287.

Kane, G.D., \& Velury, U. (2004). The role of institutional ownership in the market for auditing services: an empirical investigation. Journal of Business Research, 57(9), 976-983.

Karpoff, J.M., Malatesta, P.H., \& Walkling, R.A. (1996). Corporate governance and shareholder initiatives: Empirical evidence. Journal of Financial Economics, 42(3), 365-395.

Lee, C.C., Wang, C.W., Chiu, W.C., \& Tien, T.S. (2018). Managerial ability and corporate investment opportunity. International Review of Financial Analysis, 57, 65-76.

Lucci, J.P. (2003). Enron-The bankruptcy heard around the world and the international ricochet of Sarbanes-Oxley. Albany Law Review, 67, 211.

Mairesse, J., \& Mohnen, P. (2004). The importance of R\&D for innovation: A reassessment using French survey data. The Journal of Technology Transfer, 30(1-2), 183-197.

McConnell, J.J., \& Muscarella, C.J. (1985). Corporate capital expenditure decisions and the market value of the firm. Journal of Financial Economics, 14(3), 399-422.

McConnell, J.J., \& Servaes, H. (1990). Additional evidence on equity ownership and corporate value. Journal of Financial Economics, 27(2), 595-612.

Mishra, D.R. (2014). The dark side of CEO ability: CEO general managerial skills and cost of equity capital. Journal of Corporate Finance, 29, 390-409.

Myers, S.C. (1977). Determinants of corporate borrowing. Journal of Financial Economics, 5(2), 147175.

Nesbitt, S.L. (1994). Long-term rewards from shareholder activism: A study of the 'CalPERS effect'. Journal of Applied Corporate Finance, 6, 75-80. 
Ni, J., Kwak, W., Cheng, X., \& Gong, G. (2014). The determinants of bankruptcy for Chinese firms. Review of Pacific Basin Financial Markets and Policies, 17(2), 1450012.

Ohlson, J. (1980). Financial ratios and the probabilistic prediction of bankruptcy. Journal of Accounting Research, 18(1), 109-131.

Olley, G.S., \& Pakes, A. (1992). The dynamics of productivity in the telecommunications equipment industry. National Bureau of Economic Research, 3977.

Opler, T.C., \& Sokobin, J.S. (1995). Does coordinated institutional activism work? An analysis of the activities of the council of institutional investors. Retrieved from https://papers.ssrn.com/sol3/papers.cfm?abstract id $=46880$

Osotimehin, S., \& Pappadà, F. (2017). Credit frictions and the cleansing effect of recessions. The Economic Journal, 127(602), 1153-1187.

Parker, S., Peters, G.F., \& Turetsky, H.F. (2002). Corporate governance and corporate failure: A survival analysis. Corporate Governance: The International Journal of Business in Society, 2(2).

Ramalingegowda, S., \& Yu, Y. (2012). Institutional ownership and conservatism. Journal of Accounting and Economics, 53(1-2), 98-114.

Richardson, V.J., \& Waegelein, J.F. (2002). The influence of long-term performance plans on earnings management and firm performance. Review of Quantitative Finance and Accounting, 18(2), 161183.

Shleifer, A., \& Vishny, R. (1986). Large shareholders and corporate control. Journal of Political Economy, 94, 448-461.

Shumway, T. (2001), Forecasting bankruptcy more accurately: A simple hazard model. Journal of Business, 74, 101-124.

Smith, M.P. (1996). Shareholder activism by institutional investors: Evidence from CalPERS. The Journal of Finance, 51(1), 227-252.

Thorburn, K.S., Ayotte, K.M., \& Hotchkiss, E.S. (2013). Governance in financial distress and bankruptcy. Oxford Handbook of Corporate Governance, forthcoming.

Wahal, S. (1996). Pension fund activism and firm performance. Journal of Financial and Quantitative Analysis, pp. 1-23.

White, M.J. (1994). The costs of corporate bankruptcy: A US-European comparison. Retrieved from https://www.cesifo.org/en/publikationen/1993/working-paper/costs-corporate-bankruptcy-useuropean-comparison

Yung, K., \& Chen, C. (2018). Managerial ability and firm risk-taking behavior. Review of Quantitative Finance and Accounting, 51(4), 1005-1032.

Zmijewski, M. (1984). Methodological issues related to the estimation of financial distress prediction models. Journal of Accounting Research, 22(Supplement), 59-82.

Zorn, M.L., Norman, P.M., Butler, F.C., \& Bhussar, M.S. (2017). Cure or curse: Does downsizing increase the likelihood of bankruptcy? Journal of Business Research, 76, 24-33. 


\section{APPENDIX}

\begin{tabular}{|l|l|}
\hline Variable & Definitions \\
\hline Bankruptcy & $\begin{array}{l}\text { An indicator variable that equals } 1 \text { if the a files bankruptcy within two years of the } \\
\text { financial reporting date, and 0 otherwise; }\end{array}$ \\
\hline Ins_shares & $\begin{array}{l}\text { The number of shares owned by institutional shareholders divided by the total shares } \\
\text { outstanding; }\end{array}$ \\
\hline MA_score & Managerial ability calculated following Demerjian, et al. (2012); \\
\hline Capex & $\begin{array}{l}\text { Capital expenditure multiplied by } 100 \text { and scaled by lagged property, plant, and } \\
\text { equipment; }\end{array}$ \\
\hline NonCapex & $\begin{array}{l}\text { Sum of research and development expenditure and acquisition expenditure multiplied by } \\
100 \text { and scaled by lagged total assets; }\end{array}$ \\
\hline LogAT & The natural logarithm of the firm's total assets; \\
\hline Leverage & Liability divided by total assets; \\
\hline ROA & Income before extraoridiary item divided by total assets; \\
\hline Z_score & $\begin{array}{l}\text { Equal to } 1.2 \mathrm{~A}+1.4 \mathrm{~B}+3.3 \mathrm{C}+0.6 \mathrm{D}+1.0 \mathrm{E}, \text { where } \mathrm{A}=\text { working capital/total assets; } \mathrm{B}= \\
\text { retained earnings/total assets; } \mathrm{C}=\text { earnings before interest and tax/total assets; } \mathrm{D}= \\
\text { market value of equity/total liabilities; and } \mathrm{E}=\text { sales/total assets. }\end{array}$ \\
\hline
\end{tabular}

